\title{
CSR-Related Employment Relations and HRM Practices at Small and Medium-Sized Enterprises vs. Multinational Corporations
}

\author{
Aviad Bar-Haim ${ }^{1}\left(\mathbb{0}\right.$, , Orr Karassin' ${ }^{2}$ \\ ${ }^{1}$ Department of Management and Economics, The Open University of Israel, Ra'anana, Israel \\ ${ }^{2}$ Department of Sociology, Political Science and Communication, The Open University of Israel, Ra'anana, Israel \\ Email: aviad@openu.ac.il, karassin@openu.ac.il
}

How to cite this paper: Bar-Haim, A., \& Karassin, O. (2022). CSR-Related Employment Relations and HRM Practices at Small and Medium-Sized Enterprises vs. Multinational Corporations. Journal of Human Resource and Sustainability Studies, 10, 44-66. https://doi.org/10.4236/jhrss.2022.101004

Received: January 4, 2022

Accepted: March 4, 2022

Published: March 7, 2022

\section{Copyright $\odot 2022$ by author(s) and} Scientific Research Publishing Inc. This work is licensed under the Creative Commons Attribution International License (CC BY 4.0).

http://creativecommons.org/licenses/by/4.0/

\begin{abstract}
The article explores practices of employment relations (ER) and human resource management (HRM) in relation to corporate social responsibility (CSR) at small and medium-sized enterprises (SMEs) compared to multinational corporations (MNCs). The topic is under-researched compared to the more established separate research fields of ER, HRM, and CSR. In the field of ER \& HRM, research indicates that MNCs are inclined to adopt more up-to-date ER and HRM practices than SMEs. For CSR, research indicates that SMEs tend to adopt more positive attitudes toward CSR than MNCs, but not necessarily actual behavior. What is less known is the state of ER \& HRM practices with respect to CSR in each type of business organization. Recent research on SMEs and MNCs points to a blurring of the differences between these types of business organizations that had been observed a few decades ago. The main blurring processes can be attributed to the internationalization of SMEs. Theories explaining the business behavior of SMEs and MNCs in general are mainly complex and resource-based. These approaches, however, are not specific to CSR. The present article develops a model to explain ER \& HRM practices related to CSR based on institutional variables in the business firms' environment and on a management behavior variable. The main finding is that CSR-related ER \& HRM practices do not differ between SMEs and MNCs. Both types of firms fail to outperform regulatory demands or beyond compliance voluntary standards in CSR. The dynamics of CSR-related ER \& HRM practices at both SMEs and MNCs are discussed.
\end{abstract}

\section{Keywords}

MNCs, SMEs, Employment Relations, HRM, CSR 


\section{Introduction}

This study compares practices of employment relations (ER) and human resource management (HRM) with regard to corporate social responsibility (CSR) at small and medium-sized enterprises (SMEs) with those at multinational corporations (MNCs). The interest in SMEs and MNCs derives from their unique and differential contributions to economic growth and employment in most countries. This study addresses the question of whether these different types of business organizations have different CSR-related ER \& HRM practices.

In most countries, with both developed and emerging economies, SMEs are endorsed by governments for economic growth and providing employment (Chanut-Guieu \& Guieu, 2014; Kwiatkowska, 2010; Chitiba, 2014; Xiang \& Worthington, 2015; Karadag, 2017). ${ }^{1}$ Since more than $95 \%$ of enterprises worldwide are SMEs, and contribute up to $60 \%$ of employment and up to $40 \%$ of GDP globally (Bell, 2015), their importance is clear. In contrast to a few decades ago, when SMEs and MNCs operated in different sectors and markets, global competition and the digital economy have increasingly allowed and stimulated SMEs to operate outside their national areas of activity and compete in international markets (Dabić et al., 2020). MNCs, however, still play a central role in global and national economies (Bhatt \& Reddy, 2011; Teramae et al., 2020).

CSR is a widespread global and local business and governance phenomenon (Scherer \& Palazzo, 2011; Tengblad \& Ohlsson, 2010; Kaplan \& Kinderman, 2017; Preuss, 2019). Among its basic tenets, are responsibility toward employees, as key stakeholders, alongside responsibilities toward the environment, community, and the wider society (Dahlsrud, 2008). Practices of ER \& HRM are central to any CSR effort (Compa, 2008). But unlike responsibility toward the environment or other social obligations, ER \& HRM practices as indicators of CSR are under-researched. ${ }^{2}$

In the present study, we hypothesize that the differences between ER \& HRM practices of MNCs and SMEs are related to the differential effects of the institutional environments of the two types of organizations and their managers' orientation. Institutional factors include the consequences of ER \& HRM regulation and stakeholder expectations. To assess the soundness of the hypothesis, we develop a model and empirically test it against a small sample of firms.

The paper proceeds as follows: in Section 2, we describe the current literature comparing the CSR practices of SMEs and MNCs, with a focus on HRM/ER. In Section 3, we present the model and research hypotheses. In Section 4, we conduct the empirical analysis, describing the sample, dataset, and sources, the measurement, and the results. In Section 5, we discuss the findings and in Section 6, we conclude.

\footnotetext{
${ }^{1}$ See "Small is not necessarily beautiful," a study that questioned the assumptions of growth and employment potential of SMEs (Parker, 2000). The study agrees, however, with more recent studies that strategic development of innovative SMEs contributes to growth and quality employment.

${ }^{2}$ Exceptions are studies by Kundu and Gahlawat (2015), Sánchez and Benito-Hernández (2015), Srinivasan and Arora (2015), and Buciuniene and Kazlauskaite (2012). In addition, most ER and HRM practices have been studied as antecedents or as outcomes of CSR (see: Preuss et al., 2009).
} 


\section{Literature Review}

\subsection{CSR-Related ER \& HRM Practices}

Corporate responsibility toward employees is achieved through ER \& HRM practices, which protect the employees' individual and collective rights with respect to wages, job security, and working conditions (Compa, 2008). ER \& HRM issues are elaborated in CSR standards and codes. "Employment and industrial relations" is one of the eight thematic chapters of the OECD "Guidelines for Multinational Enterprises" (OECD, 2011). These guidelines, first adopted in 1976, are the longest-standing transnational initiative for promoting CSR (Kercher, 2007). The guidelines cover economic responsibility extensively (in five chapters), but the only chapters dealing with the social aspects of business responsibility are the chapters dedicated to environmental responsibility, employment and industrial relations, and human rights. ER \& HRM issues covered in the guidelines include freedom of association and collective bargaining, prohibition of child labor, non-discrimination, employee-management dialogue and cooperation, work conditions and wages, occupational health and safety, and local labor (OECD, 2011: pp. 35-37).

ER practices and decent work indicators are also central to the leading corporate sustainability-reporting tool, the Global Reporting Initiative (GRI) (Levy \& Brown, 2012), considered to be commonly accepted indicators of ER \& HRM in firms (Wilburn \& Wilburn, 2013). For example, the consolidated set of GRI Sustainability Reporting Standards 2016 contains 33 standards covering economic, environmental, and social issues. Of these, nine deal directly with ER \& HRM (labor/management relations, occupational health and safety, training and education, diversity and equal opportunity, non-discrimination, freedom of association and collective bargaining, child labor, and forced or compulsory labor).

Many private transnational CSR codes and standards focus on ER and HRM primarily or even exclusively. These were developed by private multinational, multi-stakeholder organizations (Compa, 2008). Based on an analysis of key guidelines and standards in the area of CSR, Remišová and Búciová (2012) identified seven main issues relating to CSR toward employees: compensation, health and safety, work conditions and corporate social politics, collective bargaining, work dignity and protection against discrimination, individual work relations and internal communication, and enforcing employee rights. Private regulatory instruments and codes relate extensively to ER \& HRM in firms, and collective and individual rights of workers and their working conditions are largely protected under International Labor Organization (ILO) conventions, international law, and ensuing national legislations.

\subsection{Researched Themes in CSR in SMEs and MNCs}

Table 1 summarizes some researched properties of CSR in SMEs and MNCs. It is more an illustrative comparison than a comprehensive literature review. The comparison covers ten topics: regulation, stakeholders' influence, cultural norms 
Table 1. Some CSR properties in SMEs and MNCs.

\begin{tabular}{|c|c|c|}
\hline Associated factors & SMEs & MNCs \\
\hline 1) Regulation & $\begin{array}{l}\text { Costs of non-compliance may be substantial (Longo } \\
\text { et al., 2005; Williamson et al., 2006). }\end{array}$ & $\begin{array}{l}\text { Must maintain operation standards across } \\
\text { countries. As a result are less responsive to local } \\
\text { conditions. }\end{array}$ \\
\hline $\begin{array}{l}\text { 2) Stakeholders' } \\
\text { influence }\end{array}$ & $\begin{array}{l}\text { Responsive to local community stakeholders } \\
\text { (Sweeney, 2007). } \\
\text { SMEs understand CSR (Jenkins, 2004; Spence, 2007). }\end{array}$ & $\begin{array}{l}\text { Responsible to a wide range of stakeholders. } \\
\text { Perceived general responsibility to society. } \\
\text { Importance of shareholders (Bondy et al., 2012; } \\
\text { Jenkins, 2004; Rodriguez \& Gomez, 2009; } \\
\text { Aguilera-Caracuel et al., 2015). }\end{array}$ \\
\hline $\begin{array}{l}\text { 3) Cultural norms and } \\
\text { expectations }\end{array}$ & More responsive because embedded in local culture. & $\begin{array}{l}\text { Working in diversified cultural environments. } \\
\text { Adapt to the expectations of local culture and } \\
\text { diversify their CSR activities accordingly. }\end{array}$ \\
\hline $\begin{array}{l}\text { 4) Organizational } \\
\text { culture }\end{array}$ & $\begin{array}{l}\text { Highly affected and reflecting owner/founder values } \\
\text { (Spence, 2007). } \\
\text { Less hierarchical, more discretion granted to } \\
\text { managers (Jenkins, 2004, 2006; Hsu \& Cheng, 2012). }\end{array}$ & $\begin{array}{l}\text { More hierarchical. Narrower managerial discretion } \\
\text { (Jenkins, 2004; Jamali et al., 2009). }\end{array}$ \\
\hline 5) Organizational size & $\begin{array}{l}\text { Fewer implementation problems (Baumann-Pauly et } \\
\text { al., 2013). } \\
\text { Fewer opportunities to apply CSR across the supply } \\
\text { chain. }\end{array}$ & $\begin{array}{l}\text { Large size makes it difficult to implement CSR } \\
\text { across the organization. } \\
\text { Many opportunities to apply CSR across the supply } \\
\text { chain. }\end{array}$ \\
\hline $\begin{array}{l}\text { 6) Availability of } \\
\text { financial resources }\end{array}$ & $\begin{array}{l}\text { Financial strength might constrain CSR (Lepoutre \& } \\
\text { Heene, 2006; Kusyk \& Lozano, 2007; Sweeney, 2007; } \\
\text { Jenkins, 2004; Hsu \& Cheng, 2012). }\end{array}$ & $\begin{array}{l}\text { Available financial resources allow for easier } \\
\text { adoption of CSR (Aguilera-Caracuel et al., 2015). }\end{array}$ \\
\hline $\begin{array}{l}\text { 7) Natural resource } \\
\text { dependencies }\end{array}$ & $\begin{array}{l}\text { In developed countries, they are less } \\
\text { resource-dependent. } \\
\text { In developing countries, they may be as } \\
\text { resource-dependent as MNCs. }\end{array}$ & $\begin{array}{l}\text { Reliant on exploiting local advantages in resources } \\
\text { (Strike et al., 2006; Surroca et al., 2013). }\end{array}$ \\
\hline $\begin{array}{l}\text { 8) Human resources } \\
\text { management }\end{array}$ & $\begin{array}{l}\text { Based on local employment and contributing in this } \\
\text { way to CSR (Jenkins, 2006, Nielsen \& Thomsen, } \\
\text { 2009). }\end{array}$ & $\begin{array}{l}\text { Diversification in human resources allows for } \\
\text { easier application of CSR. } \\
\text { More CSR-oriented training. } \\
\text { Not necessarily reliant on local employment } \\
\text { (Chapple \& Moon, 2005; Mijatovic \& Stokic, 2010). }\end{array}$ \\
\hline $\begin{array}{l}\text { 9) Managers' attitudes } \\
\text { toward CSR }\end{array}$ & $\begin{array}{l}\text { Mainly affected by owners' perceptions (Vo, 2011; } \\
\text { Hsu \& Cheng, 2012). }\end{array}$ & $\begin{array}{l}\text { Informed by international standards and trends in } \\
\text { management. }\end{array}$ \\
\hline $\begin{array}{l}\text { 10) Importance of CSR } \\
\text { communication }\end{array}$ & $\begin{array}{l}\text { Communication of CSR is usually not central (Lee et } \\
\text { al., 2016; Jamali et al., 2009). }\end{array}$ & $\begin{array}{l}\text { Communication and reporting of CSR is central } \\
\text { (Mousiolis et al., 2015; Baumann-Pauly et al., 2013; } \\
\text { Jamali et al., 2009). }\end{array}$ \\
\hline
\end{tabular}

and expectations, organizational culture, organizational size, availability of financial resources, natural resource dependences, HRM, managers' attitudes toward CSR and importance of CSR communication, dependence on natural resources, organizational cultural norms, managerial attitude, and the importance of communication.

Table 1 shows that SMEs are generally more sensitive to local conditions for 
the success of CSR practices than MNCs are. SMEs are more beholden to local stakeholders, and are constrained by compliance behavior in response to either formal regulations or community norms and pressures. They are less flexible in hiring and firing because of their responsibilities toward employment in their communities. Local owners have limited access to resources, and their personal attitudes in adopting CSR practices are crucial compared to the personal attitudes and values of top managers in MNCs (Jenkins, 2004, 2006; Hsu \& Cheng, 2012). SMEs are more reliant on local stakeholders and community legitimation (Sweeney, 2007; Jenkins, 2004; Spence, 2007). They are dependent on the local workforce, which is a key concern for their mission to contribute to local employment (Jenkins, 2006, Nielsen \& Thomsen, 2009).

By contrast, MNCs must respond to a wider set of stakeholders and local cultures, and apply much more complicated global standards. They have different incentives for adopting CSR. Yet, some attributes make MNCs a more promising business setting for achieving CSR performance, such as the availability of financial resources (Aguilera-Caracuel et al., 2015) and their perceived responsiveness to a wider range of stakeholders (Bondy et al., 2012; Jenkins, 2004; Rodriguez \& Gomez, 2009; Aguilera-Caracuel et al., 2015). But there is little conclusive research evidence on which setting is more conducive to CSR, SMEs or MNCs, when compared in a similar national setting, and findings have been mixed.

\subsection{ER \& HRM in SMEs and MNCs}

Studies on ER \& HRM are often reported separately for SMEs and MNCs. One dilemma SMEs face in their attempt to improve business performance is the choice of adopting universal HRM best practices or a contingency approach. The former assumes that there is a set of best ER or HRM practices (such as those of workforce planning, recruitment, selection, training and development, appraisal and evaluation, wages and fringe benefits administration) that are universally effective in all situations. Adopting them leads to superior organizational performance. The latter approach directs SMEs to adopt ER \& HRM practices that take into account local constraints and limitations, such as labor unions and national cultural norms (Edwards et al., 2016, and see the specific relevance of employment relations in Wilkinson, 1999; Kinnie et al., 1999; Mallett \& Wapshott, 2017). It suggests that to be effective, ER \& HRM policies must be consistent with specific characteristics of the organization and its external environment, and better performance is based on external and internal fit (Cooper \& Burke, 2011; Burke, 2011; Fabi et al., 2009; Harney \& Dundon, 2006).

ER \& HRM practices in MNCs are also a result of a choice between the centralized, ethnocentric, uniform, and homogeneous policy of the MNC country of origin, and a policy of localization of practices according to local conditions (Edwards et al., 2016). The research of Dabić et al. (2020) on HRD in SMEs analyzes the demanding effort to attract, compensate, motivate, and retain em- 
ployees in SMEs, and to carry out successful talent management (TM). It does not refer, however, to the critical role played by the owner-manager in HRD in general, and in management in particular.

In both SMEs and MNCs, the real patterns of ER \& HRM policies and practices are not found at the extreme ends of the theoretical choices, and display a mix with different emphases (Edwards et al., 2016; Maharjan \& Sekiguchi, 2016; Chen et al., 2018; Yu, Park, \& Cho, 2007, Sheehan, 2013). We found no consistent support for the argument that the HRM practices of SMEs are ad hoc, opportunistic, and vary from one organization to the next (Tsai, 2010: p. 1693); see the summarizing tables of HRM practices in SMEs: Brand and Bax, 2002: p. 453 and Burke, 2011: p. 20).

\section{A Model of ER \& HRM CSR Practices in SMEs and MNEs}

\subsection{Model Variables and Relationships}

To develop our model, we combined two inquiry levels: a macro institutional and resource-based view and a mezzo level of organizational behavior (O'Connor et al., 2017; Dabić et al., 2020). To the best of our knowledge, there have yet to be studies that focus on the detailed differences in ER \& HRM CSR related-practices in SMEs compared to MNCs (e.g. Harney \& Nolan, 2014 which address HRM in SMEs do not address the differences between them and MNCs in the context of CSR). This is the focus of our study.

ER \& HRM may deviate from other responsibility areas of CSR (environment, society, corporate governance, product responsibility), therefore firms may respond differently to local and global forces and constraints. This observation on the uniqueness of ER \& HRM practices in the realm of other CSR practices has been initially reported by Bar-Haim and Karassin (2018). In that study, we found that ER \& HRM practices are not fully at the discretion and subject to the influence of firms. These practices are not part of the firms' voluntary (beyond compliance) CSR policies, but rather are dominated by external regulatory requirements and proved to be within compliance-oriented corporate social behavior rather than beyond compliance CSR. In the current model, we revisit this finding to examine whether differences can be found between SMEs and MNCs nevertheless.

The following model on the use of ER \& HRM CSR by SMEs and MNCs controls for three sets of variables: two sets of institutional variables and one set of managers' orientation towards CSR (Figure 1). The institutional variables address the institutional environment in which corporations operate and are required to follow appropriate CSR practices, pursuant to legal, social, and cultural pressures (Campbell, 2007). Institutional theory conceptualizes CSR as the responsibility of firms to behave in a fashion that is "desirable in terms of objectives and values of society" (Bowen, 1953: p. 6) and to bring "corporate behavior up to a level where it is congruent with prevailing social norms, values and 


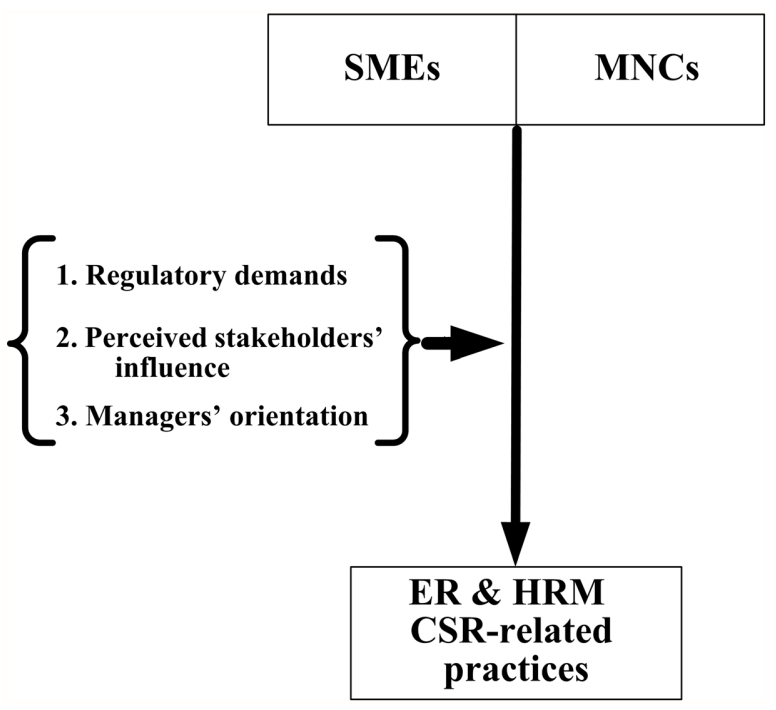

Source: Authors

Figure 1. A model of ER \& HRM CSR practices in SMEs and MNCs.

expectations of performance" (Sethi, 1975: p. 62). Yet, perceived institutional forces reflect also a resource-based view (Dabić et al., 2020) that helps explain the will and limitations of organizations to pursue CSR-related ER \& HRM practices.

We defined and measured two composite institutional variables. First, "regulatory demands" are central because they determine the minimum compliance level and relate the demands made by the regulator from firms. It has been noted that strong regulation with a credible threat of enforcement is necessary for voluntary self-regulation CSR to be effective and achieve beyond compliance levels (Lenox \& Nash, 2003; Bansal \& Roth, 2000, Bansal, 2005; Karassin \& Bar-Haim, 2019).

Second is a composite variable, the "perceived stakeholders' influence" of managers, which measures the perceived influence of external stakeholders on the performance of the firm in the field of CSR in direct or informal ways (Freeman, 1984). Stakeholders are by nature diverse and may include a multitude of actors and groups, acting at the local, national, and supra-national levels. Stakeholders are likely to include the firm's customers, employees, suppliers, financial institutions such as banks and insurers, the surrounding community, and NGOs (Donaldson \& Preston, 1995; Clarkson, 1995). Stakeholders influence the adoption of CSR practices through the market and supply chain (Mohr \& Webb, 2005). Despite possible conflicting interests, the prevailing view has been that stakeholders influence CSR (Corcoran \& Shackman, 2007; Ditlev-Simonsen \& Wenstøp, 2013; O’Riordan \& Fairbrass, 2014). Answering stakeholders' CSR expectations may benefit the firm by increasing revenues or reducing costs, increasing the firm's competitiveness, and promoting innovation (Waddock \& Graves, 1997). Stakeholders also influence firms' social responsibility through public pressure, negative media attention, and potential damage to reputation (van Erp, 2011; Thornton et al., 2009). 
We added managers' CSR orientation as a control variable because its positive manifestation is likely to have a strong influence on firm-level CSR engagement (Weaver et al., 1999a) and outcomes (Hemingway, 2005; Aguilera \& Jackson, 2010). Both instrumental reasons (the perception that CSR is good for business) and normative ones (a sense of responsibility and duty - doing good) are possible motivations for CSP (Bansal \& Roth, 2000; Graafland et al., 2007; Mudrack, 2007). One study has shown that organizations that undertake CSR programs because of external influences, without commitment by management, engage in "decoupled CSR activities", which are disconnected from ongoing core business activities (Weaver et al., 1999b).

\subsection{Research Hypotheses}

The literature reviewed above does not provide an unequivocal answer to our research question, whether the type of business organization (MNCs or SMEs) affects the CSR-related ER \& HRM practice. We therefore suggest the following exploratory hypotheses:

H1: SMEs and MNCs working in the same country are expected to differ substantially in their CSR-related ER \& HRM practices.

This hypothesis rests on the established differences in goals, strategies, structures, resources, environments, and management between these two types of business organizations.

We formulated additional exploratory hypotheses regarding the inconclusive findings concerning the advantage of SMEs in applying CSR-related ER \& HRM practices.

H2: Local (national) regulatory demands strengthen CSR practices of ER \& HRM in SMEs more than in MNCs because SMEs are informed only by local (national) regulators, whereas MNCs are also informed by international and transnational regulatory standards, which they implement.

H3: ER \& HRM CSR practices at SMEs are affected more strongly by perceived local stakeholders' influence than at MNCs. The reason for this may be that SMEs are more attuned to community relations affected by local employment practices.

H4: ER \& HRM CSR practices at SMEs are affected more strongly by managers' orientation toward CSR than at MNCs. The reason for this may be the managers' proximity to the local workforce and community, and their familiarity with them.

\section{Empirical Analysis}

\subsection{The Sample}

We investigated 11 Israeli industrial firms (the "firm sample"). At these firms, we interviewed 54 top managers, an average of 5 managers per firm ("managers' sample"). We used an interview guide and codified the answers to the open-ended questions. In addition, 412 workers of the firms completed a questionnaire, an 
average of 37 workers per firm ("workers' sample").

A third of the firm sample consisted of MNCs. The industrial sectors covered in the firms' sample were chemical, metal, computer components, electronics, and optical equipment, rubber and plastic, machinery and equipment. Most of the firms were privately held and few were publicly traded. Most of the firms exported over $40 \%$ of their products, operating in saturated markets, with national and international competitors; the rest operated in smaller markets with fewer competitors. The characteristics of the sample and its geographical coverage of the regions of the country suggest that it is an appropriate one for describing CSR in Israel. The managers' sample included senior managerial positions in each enterprise (always including the CEO, CFO, and HRM officer); $28 \%$ were female and $72 \%$ male. The workers sample was selected randomly; $36 \%$ were female and $64 \%$ male.

The Israeli industrial sector is required to comply with a variety of employment-related regulations and organizational health and safety (OHS) regulations, based on requirements set out in international agreements (Lurie, 2013). Employment laws specify the rights of salaried employees, and grant them more rights than to contract workers or self-employed individuals (Ben Israel, 2002). Israeli industry is subject to comprehensive legislation concerning non-discrimination and equal opportunities. Examples are The Law of Equal Opportunities at Work (1988), Collective Bargaining Law (1957), Minimum Wage law (1987), The Law of Safety in the Workplace (1970), and The Law on the Organization of Inspection of Work (1954), which requires firms to devise safety plans and appoint OHS officers (Ben Israel, 2002).

\subsection{The Data Set}

To measure the model variables, we collected data from the industrial enterprises, managers, and workers) at different levels of measurement (regulatory records, organizational records, assessments of performance by managers, and attitudes of and managers). To analyze all the variables at the same measurement level, we assigned the mean scores of the 54 managers to the 412 workers. This is an expansion method, the reverse of the common aggregation method (for this methodology, see Karassin \& Bar-Haim, 2016; Bar-Haim \& Karassin, 2018). Similarly, we assigned the scores of the regulatory records of the 11 enterprises to the workers sample.

In this way, we produced a data set of 412 respondents who have the additional scores of their managers and of their enterprises. To check for obvious possible biases derived from the considerable differences of sample sizes and variances, we aggregated the mean of the model variables with the managers sample $(\mathrm{N}=54)$ and the firms sample $(\mathrm{N}=11)$. Next, we examined the patterns of parametric (Pearson's $\mathrm{r}$ ) and non-parametric (Spearman's rank-order rho) correlations between the variables. Except for 1 out of 45 pairs of correlations in the model, there were no significant differences between the correlation matrices at 
the level of 412 respondents, of 54 managers, and of 11 firms. Although larger samples of firms and managers would reduce the risk of bias in the expansion procedure, the consistent and stable patterns of the correlation matrices reduce the concern for the reliability of the statistical results.

\subsection{Measurement}

The CSR-related ER \& HRM scale (the dependent variable) is an eight-item scale covering four areas of CSR-related ER \& HRM practices: a) equal remuneration and employment type (HRM practice), b) freedom of association (employment practice), c) health and safety in work conditions (employment practice), and d) education and training (HRM practice). Diversity and equal opportunity practices were excluded because of data inconsistencies. The scale was constructed using an optimal scaling procedure because the indicators vary in content and measures (Table 2). ${ }^{3}$

1) Regulatory demands scale. This scale relates to regulatory employment inspections, administrative proceedings, and OHS accident-related inspections (Table 3). It is constructed using an optimal scaling procedure for the same measurement reasons mentioned regarding the scale in Table 2 (see footnote 7).

2) Perceived stakeholders' influence is assessed by managers' perceptions of the degree of influence of the various stakeholders on the ongoing activities or the future of the firm (responses were provided on a Likert-type scale of 4 categories,

Table 2. Standardized optimal CSR-related ER \& HRM scale.

\begin{tabular}{|c|c|c|c|c|c|c|c|}
\hline $\begin{array}{l}\text { CSR-related ER \& } \\
\text { HRM practice }\end{array}$ & Item & Weight & $\mathbf{N}$ & Min. & Max. & Mean & SD \\
\hline \multirow{3}{*}{$\begin{array}{l}\text { Equal remuneration and } \\
\text { employment type }\end{array}$} & 1) \% Full-time employees & 0.976 & 412 & 60.0 & 99.0 & 86.511 & 12.679 \\
\hline & 2) $\%$ Part-time employees & 0.728 & 412 & 0.0 & 29.6 & 5.100 & 8.009 \\
\hline & 3) \% Contract workers & 0.730 & 412 & $-30.0^{*}$ & 0.01 & -9.022 & 10.131 \\
\hline \multirow[t]{2}{*}{ Freedom of association } & 1) \% Employees covered by collective agreement & 0.683 & 412 & 0.0 & 100.0 & 58.766 & 48.633 \\
\hline & 2) \% Employees belonging to a labor union & 0.888 & 412 & 0.0 & 100.0 & 16.415 & 34.001 \\
\hline \multirow[t]{2}{*}{$\begin{array}{l}\text { Health and safety in } \\
\text { work conditions }\end{array}$} & $\begin{array}{l}\text { 1) \# Absence days per worker due to accidents } \\
\text { and occupational sickness }\end{array}$ & 0.958 & 412 & $-4322^{\star}$ & -3.00 & -412.5 & 1079.9 \\
\hline & 2) \# Absence days per worker, weighted for size & 1.000 & 412 & $-17.71^{*}$ & -0.04 & -1.766 & 4.449 \\
\hline Education and training & $\begin{array}{l}\text { 1) \# Annual hours of occupational training per } \\
\text { worker }\end{array}$ & 0.971 & 412 & 0.01 & 105 & 14.466 & 26.533 \\
\hline \multicolumn{2}{|l|}{ Optimal ER \& HRM scale } & & 412 & -0.99 & 2.53 & 0.0 & 1.00 \\
\hline Cronbach's Alpha & $\%$ of Variance & & & & & & \\
\hline 0.978 & 86.670 & & & & & & \\
\hline
\end{tabular}

${ }^{*}$ Minus indicates a positive indicator (fewer contract employees or fewer work accidents)

${ }^{3}$ When scale items are different in their contents and measures, the recommended scaling method is Optimal Scaling, using IBM SPSS optimal scaling procedure. This method combines different measures into a multi-item scale (Meulman et al., 2004). 
ranging from $1=$ No influence to $4=$ A great deal of influence) (Table 4 ).

3) Managers' orientation toward CSR. This is an additive scale of managers' attitudes and behavior toward CSR performance, based on three Likert-type items obtained from the managers' sample (Table 5).

\subsection{Results}

We conducted comparisons of SMEs and MNCs on their practices of CSR-related

Table 3. Standardized optimal HRM and employment regulatory demands scale.

\begin{tabular}{|c|c|c|c|c|c|c|c|}
\hline & \multicolumn{2}{|c|}{ Items } & Weights & Min. & Max. & Mean & SD \\
\hline & \multicolumn{2}{|c|}{ Random inspections } & 1.00 & 0.00 & 12.00 & 4.06 & 3.577 \\
\hline & \multicolumn{2}{|c|}{ Administrative proceeding } & 1.00 & 0.00 & 3.00 & 1.09 & 0.95 \\
\hline & \multicolumn{2}{|c|}{ OHS accident-related inspections } & 1.00 & 0.00 & 48.00 & 20.96 & 16.04 \\
\hline & \multicolumn{2}{|c|}{$\begin{array}{c}\text { Optimal ER \& HRM } \\
\text { regulatory demands scale }\end{array}$} & & -3.33 & 0.31 & 0.00 & 1.00 \\
\hline Cronbach's Alpha & Eigenvalue & $\%$ of Variance & & & & & \\
\hline 1.000 & 3.000 & 100 & & & & & \\
\hline
\end{tabular}

Table 4. Perceived stakeholders' influence.

\begin{tabular}{lll}
\hline Item & Reliability & $\mathrm{N}$ \\
\hline
\end{tabular}

Degree of perceived influence of the following stakeholders on the ongoing activities or the future of the firm
1) Regulator
Single item
$\begin{array}{lll}412 & 3.40 & 0.49\end{array}$
2) Workers
Spearman-Brown $=0.55(2$ items $)$
$\begin{array}{lll}412 & 3.28 & 0.27\end{array}$
3) Community
Cronbach $\alpha=0.69$ (2 items)
$\begin{array}{lll}412 & 2.42 & 0.52\end{array}$
4) Financial institutions
Cronbach $\alpha=0.69$ (2 items)
$\begin{array}{lll}412 & 2.09 & 0.74\end{array}$
5) Customers
Cronbach $\alpha=0.71$ (2 items)
$\begin{array}{lll}412 & 3.38 & 0.48\end{array}$
6) Suppliers
Cronbach $\alpha=0.60$ (2 items)
$\begin{array}{lll}412 & 2.61 & 0.46\end{array}$

Table 5. Managers' orientation scale.

\begin{tabular}{llcccc}
\hline \multicolumn{1}{c}{ Item } & N & Min. & Max. Mean SD \\
\hline $\begin{array}{l}\text { 1) Management emphasizes receiving credible } \\
\text { information on CSR performance }\end{array}$ & 52 & 2 & 4 & 3.37 & 0.69 \\
$\begin{array}{l}\text { 2) Management uses various strategies } \\
\text { to advance CSR goals }\end{array}$ & 54 & 1 & 4 & 2.85 & 0.98 \\
$\begin{array}{l}\text { 3) Management is expected to achieve CSR } \\
\text { performance in addition to economic performance }\end{array}$ & 54 & 1 & 4 & 3.17 & 0.86 \\
\hline & Reliability & N & Mean SD \\
\hline $\begin{array}{l}\text { Managers' orientation scale } \\
\text { Cronbach } \alpha=0.69 \\
(3 \text { items })\end{array}$ & 412 & 3.33 & 0.32 \\
\hline
\end{tabular}


ER \& HRM performance using t-test and ANCOVA analyses. Table 6 shows that a simple t-test on the difference of means of ER \& HRM between SMEs and MNCs does not reveal a significant difference. Therefore, H1 in our study is not supported.

In addition, contrary to our hypotheses that the control variables (regulatory demands, perceived influence of stakeholders, and managers' orientation towards CSR) will favor ER \& HRM practices of CSR in SMEs over MNCs, results in Table 7 show that most of them were higher in the MNCs than in the SMEs in our sample. An exception is the perceived influence of workers as stakeholders, where the difference between SMEs and MNCs is not significant. These findings do not support $\mathrm{H} 2, \mathrm{H} 3$, and $\mathrm{H} 4$.

Table 6. Independent samples t-test between SMEs and MNCs on CSR-related ER \& HRM practices.

\begin{tabular}{ccccccc}
\hline & \multicolumn{5}{c}{ t-test for Equality of Means } \\
\cline { 2 - 7 } $\begin{array}{c}\text { Dependent: ER \& } \\
\text { HRM practices }\end{array}$ & $\mathbf{t}$ & $\mathrm{df}$ & $\begin{array}{c}\text { Sig. } \\
\text { (2-tailed) }\end{array}$ & $\begin{array}{c}\text { Mean } \\
\text { Difference }\end{array}$ & $\begin{array}{c}\text { Std. Error } \\
\text { Difference }\end{array}$ \\
\hline $\begin{array}{c}\text { Equal variances assumed } \\
\text { Equal variances not assumed }\end{array}$ & 1.413 & 410 & $0.159^{*}$ & 0.150 & 0.106 \\
\hline
\end{tabular}

${ }^{\star}$ Not significant.

Table 7. Means of control variables (covariates) in SMEs and MNCs.

\begin{tabular}{|c|c|c|c|c|c|}
\hline & SME_MNC & $\mathbf{N}$ & Mean & $\begin{array}{c}\text { Std. } \\
\text { Deviation }\end{array}$ & $\begin{array}{c}\text { Std. Error } \\
\text { Mean }\end{array}$ \\
\hline \multirow[t]{2}{*}{ 1) Regulatory demands } & $1 \mathrm{SME}$ & 283 & -0.138 & 1.183 & 0.070 \\
\hline & $2 \mathrm{MNC}$ & 129 & 0.304 & 0.007 & 0.001 \\
\hline \multirow[t]{2}{*}{ 2) Regulator as stakeholder } & $1 \mathrm{SME}$ & 283 & 3.278 & 0.485 & 0.029 \\
\hline & $2 \mathrm{MNC}$ & 129 & 3.882 & 0.137 & 0.012 \\
\hline \multirow[t]{2}{*}{ 3) Workers* } & $1 \mathrm{SME}$ & 283 & 3.264 & 0.239 & 0.014 \\
\hline & $2 \mathrm{MNC}$ & 129 & 3.246 & 0.270 & 0.024 \\
\hline \multirow[t]{2}{*}{ 4) Community } & $1 \mathrm{SME}$ & 283 & 2.279 & 0.519 & 0.031 \\
\hline & $2 \mathrm{MNC}$ & 129 & 2.581 & 0.292 & 0.026 \\
\hline \multirow[t]{2}{*}{ 5) Financial institutions } & $1 \mathrm{SME}$ & 283 & 2.327 & 0.704 & 0.042 \\
\hline & $2 \mathrm{MNC}$ & 129 & 1.373 & 0.432 & 0.038 \\
\hline \multirow[t]{2}{*}{ 6) Customers } & $1 \mathrm{SME}$ & 283 & 3.420 & 0.467 & 0.028 \\
\hline & $2 \mathrm{MNC}$ & 129 & 3.594 & 0.466 & 0.041 \\
\hline \multirow[t]{2}{*}{ 7) Suppliers } & $1 \mathrm{SME}$ & 283 & 2.484 & 0.446 & 0.027 \\
\hline & $2 \mathrm{MNC}$ & 129 & 2.957 & 0.164 & 0.014 \\
\hline \multirow[t]{2}{*}{ 8) Managers' orientation towards CSR } & $1 \mathrm{SME}$ & 283 & 3.170 & 0.236 & 0.014 \\
\hline & $2 \mathrm{MNC}$ & 129 & 3.657 & 0.090 & 0.008 \\
\hline
\end{tabular}

${ }^{\star}$ Mean difference is not significant in t-test whether equal variances is or is not assumed. 
Table 8 shows an ANCOVA analysis that combines the effects of all variables in the model. The weights of the explaining variables are displayed in the Sum of Squares column. (For a somewhat comparable strategy, see Orlitzky et al., 2017). We can see that two variables have a considerable explanatory power: perceived influence of workers as stakeholders (29\% of explained variance) and managers' orientation toward CSR (23\%). Perceived financial institutions as stakeholders contribute $10 \%$ to the explanatory power of the model, and the other variables make only modest contributions. The difference between SMEs and MNCs on CSR-related ER \& HRM practices, which is central to our thesis, is negligible $(0.5 \%)$, and the small size of the sum squares of the regulatory demands is dwarfed by perceived institutional influence of the stakeholders, and managers' orientations. The overall power of the model is $84 \%$ of the variance of ER \& HRM.

Other parameters in Table 8, Omega squared $\left(\omega^{2}\right)$ (measuring the effect of each component in the model) and SCC (measuring the relationship between each component in the model and the dependent variable) reveal that the perceived influence of workers as stakeholders and managers' orientation have large effects, and that perceived influence of the regulator has medium $\omega^{2}$ effects. With regard to SCC, perceived influence of the regulator as a stakeholder and managers' orientation are strongly related to the dependent variable, but note the direction of the correlations of this parameter: perceived influence of workers, perceived influence of customers, and managers' orientation are negatively related to the practices of the ER \& HRM scale. Thus, there is no difference in

Table 8. ANCOVA and canonical correlations. The dependent variable is CSR-related ER \& HRM.

\begin{tabular}{lcccccccc}
\hline \multicolumn{1}{c}{ Source of variance } & $\begin{array}{c}\text { Type I Sum } \\
\text { of Squares }\end{array}$ & $\%^{1}$ & df & $\begin{array}{c}\text { Mean } \\
\text { Square }\end{array}$ & F & p & $\begin{array}{c}\text { Omega } \\
\left.\text { Squared ( } \omega^{2}\right)\end{array}$ & $\begin{array}{c}\text { Standardized Canonical } \\
\text { Correlation (SCC) }\end{array}$ \\
\hline 1) SME_MNC & 1.996 & $0.5 \%$ & 1 & 1.00 & $12.05<0.001$ & 0.004 & 1.533 \\
2) Regulatory demands & 19.038 & $5 \%$ & 1 & 19.04 & $114.99<0.001$ & 0.05 & 1.445 \\
3) Influence of regulator & 25.013 & $6 \%$ & 1 & 25.01 & $151.08<0.001$ & $0.06^{*}$ & -1.128 \\
4) Influence of workers & 119.049 & $29 \%$ & 1 & 119.05 & $719.04<0.001$ & $0.29^{* *}$ & 1.053 \\
5) Influence of community & 10.662 & $2.5 \%$ & 1 & 10.66 & $64.40<0.001$ & 0.03 & 1.959 \\
6) Influence of financial institutions & 42.145 & $10 \%$ & 1 & 42.15 & $254.55<0.001$ & 0.10 & -2.689 \\
7) Influence of customers & 12.289 & $3 \%$ & 1 & 12.29 & $74.23<0.001$ & 0.03 & 1.368 \\
8) Influence of suppliers & 21.304 & $5 \%$ & 1 & 21.30 & $128.67<0.001$ & 0.05 & -4.618 \\
9) Managers' orientation towards CSR & 93.946 & $23 \%$ & 1 & 93.95 & $567.42<0.001$ & $0.23^{* *}$ & \\
\multicolumn{1}{c}{ Error } & 66.558 & $16 \%$ & 402 & 0.17 & & & &
\end{tabular}

${ }^{1}$ We follow Orlitzky et al. (2017) in calculating the percentage of sum squares of each explaining variable, because we apply type I sums of squares, which sum to $100 \%$. Note our assumed order of the numbered explanatory predictors in the table. ${ }^{\star}$ Medium effect; ${ }^{* *}$ Large effect. 
our sample between SMEs and MNCs regarding CSR-related ER \& HRM practices. For both types of business organizations, the mostly negative explanatory factors are perceived influence of workers as stakeholders and managers' orientation.

\section{Discussion}

Contrary to H1, SMEs were not found to have better institutional and managerial conditions for achieving more effective CSR-related ER \& HRM practices than MNCs. This is consistent with similar recent findings that point to the fact that SMEs and MNCs increasingly face similar institutional environments, as SMEs are increasingly operating outside their national borders and competing on international markets (Dabić et al., 2020). As a result, SMEs engaged in exports may be exposed to regulatory standards and competitive challenges similar to those of MNCs. For example, in employment relations, organizational health and safety (OHS) is protected under international law: the ILO Convention 155, "Occupational Health \& Safety Convention" and Protocol 155, 1981 set the basic standards for OHS. Although OHS approaches to legislation, regulation, and enforcement vary among nations, most countries' standards for health and safety conditions are highly codified and based on ILO standards at a minimum (Montero et al., 2009). In view of global standards, which are supported by national and international labor organizations, the local influence of workers as stakeholders is weakened, which may explain the negative correlation with the ER \& HRM scale in the case of both SMEs and MNCs.

As noted above, the compliance-oriented nature of CSR-related ER \& HRM in general, and in our study as well, imposes a limit on the degrees of freedom of intra-organizational mechanisms. ${ }^{4}$ This interpretation is reinforced by studies that have demonstrated that ER \& HRM practices and decision-making are only partially within the authority and direct control of managers and HR officers (Novicevic et al., 2011, Bar-Haim \& Karassin, 2018). In most cases, managers have less freedom in dealing with ER \& HRM issues than in other managerial domains, such as finance and technology (Boselie et al., 2009). Their managerial flexibility is constrained by the institutional environment, such as the power of labor unions and various political factors and conditions (Staehle \& Schirmer, 1992). In addition, the ER \& HRM function is less influential on management boards, although it is more important at multinational firms (Sumetzberger, 2005; Jackson \& Rathert, 2016). Its dual function in advancing the firm's interests and responding to the needs of its workforce weakens its effect internally. We suggest that these constraints and the ambivalence of the ER \& HRM facet may impede CSR-motivated managers from attaining high performance in this area at both SMEs and MNCs.

The negative effect of managers' orientation on ER \& HRM may point to a gap between their proclaimed attitudes, motivations, and strategies regarding ${ }^{4}$ See Sharon Clarke (2011, Ch. 8, in: Cooper and Burke, 2011) on the poor performance of SMEs on health and safety. 
CSR and their commitment to excel in matters related to ER \& HRM. This gap between promising policy statements and real performance is described as "decoupling" (Graafland \& Smid, 2016). Institutional theory suggests that the main reason for companies to decouple is the tension between the need of a company to gain social legitimacy and facing pressures it faces to maintain efficiency and profitability (Graafland \& Smid, 2016). The quest for social legitimacy can make it attractive to uphold the public image of a positive social actor, without committing to the necessary actions (Harrison \& Freeman, 1999). Several studies found that such legitimacy pressures result in decoupling processes whereby corporate responses to external demands remain more symbolic than substantive (Jamali, 2010; Okhmatovskiy \& David, 2012).

In the case of CSR-related ER \& HRM performance, the motivation for decoupling may be even stronger because of the less visible nature of ER \& HRM than of the environmental, social, and product aspects of CSR. In other words, managers may find it easier to create an image of obligation to CSR without actually taking measures to address ER \& HRM beyond compliance. This may occur because complying with localized international regulatory standards of ER \& HRM satisfies stakeholders' demands and is sufficient to achieve the required expectations in this field, without exerting the extra effort necessary to implement beyond compliance activities. In this respect, we did not find differences in behavior between SMEs and MNCs.

The lack of substantive differences in ER \& HRM practices between SMEs and MNCs may also be explained by the growing influence of CSR as a global business agenda and trend in corporate governance (Crowther \& Aras, 2010). Globalization has diffused CSR ideas and practices through multiple paths to businesses worldwide, and is no longer the exclusive domain of MNCs (Scherer \& Palazzo, 2011; Tengblad \& Ohlsson 2010; Kaplan \& Kinderman, 2017; Preuss, 2019). SMEs are able to learn ER \& HRM practices and serve as vehicles for the diffusion of CSR ideals, and they seem to implement these to degrees that are not substantially different from those of MNCs, attesting to the forces exerted by transnational diffusion on these issues (Ayuso et al., 2013; Morsing \& Perrini 2009). At the same time, the adoption of CSR practices by MNCs adjusts to local institutional circumstances to address local stakeholder preferences and expectations. Scholarly work has stressed the institutional and cultural embeddedness of some of the CSR aspects and related practices (Jackson \& Apostolakou, 2010; Kinderman, 2009; Aguilera \& Jackson, 2010). Hence, ER \& HRM practices appear to converge to a large degree. The internationalization of CSR, as well as ER \& HRM, pushes SMEs to adopt global norms and standards, whereas MNCs adjust practices to fit local demands and expectations, thereby continually reducing gaps in actual practice.

\section{Conclusion}

The obvious limitations of our sample size and the geographic focus on Israeli 
SMEs and MNCs require caution in generalizing the results. The study is based on a sample from a small OECD country. According to the study model, institutional cultural and economic variations between countries may affect the results and limit the ability to generalize them. Yet, the study should be replicable in other countries because of our relatively straightforward data collection method. Future studies should broaden the scope of the dependent ER/HRM variable and extend the sample size, potentially adding firms from several countries for comparison.

This study may be of importance to the CSR field, because it demonstrates that contrary to other spheres of CSR, such as environment and society, ER \& HRM practices are not fully at the discretion of the firms and therefore there are no significant differences between the practices of MNCs and SMEs in these areas. The common factors that drive differences in the use of CSR-related ER \& HRM practices are institutional variables and managerial orientation rather than the multinational or local profile of the businesses. In both forms of enterprise, the use ER \& HRM practices of CSR remains highly dependent on external institutional pressures and managerial behavior. These external pressures are responsible for its use, although not all regulatory demands and stakeholder pressures may have the same force or direction. For SMEs as well as MNCs, these effects contrast with the limited power and freedom of action that internal organizational mechanisms hold over ER \& HRM. The negative relationship of managers' orientation toward CSR and the use of its ER \& HRM practices accentuates the ambivalent nature of CSR-related ER \& HRM practices as well as the ambivalence of managers towards its use, irrespective of whether the corporation is an SME or MNC.

From a managerial perspective, reducing the ambiguity of CSR-related ER \& HRM practices is achievable through strict compliance with regulatory demands in this area. In most developed countries, ER \& HRM regulation is usually based on international standards; therefore, compliance achieves the basic goals of CSR-related ER \& HRM and preserves the reputation of responsible employers, without striving for beyond compliance performance. But firms engaged in CSR programs can adopt beyond compliance CSR practices in the area of ER \& HRM within the framework of strategic HRM of the firm. Strategic HRM may incorporate CSR practices of ER \& HRM as part of its vision and needs, not only for the sake of compliance with local and international standards.

\section{Conflicts of Interest}

The authors declare no conflicts of interest regarding the publication of this paper.

\section{References}

Aguilera, R. V., \& Jackson, G. (2010). Comparative and International Corporate Governance. Academy of Management Annals, 4, 485-556.

https://doi.org/10.5465/19416520.2010.495525 
Aguilera-Caracuel, J., Guerrero-Villegas, J., Vidal-Salazar, M., \& Delgado-Márquez, B., L. (2015). International Cultural Diversification and Corporate Social Performance in Multinational Enterprises: The Role of Slack Financial Resources. Management International Review, 55, 323-353. https://doi.org/10.1007/s11575-014-0225-4

Ayuso, S., Roca, M., \& Colomé, R. (2013). SMEs as “Transmitters” of CSR Requirements in the Supply Chain. Supply Chain Management: An International Journal, 18, 497-508. https://doi.org/10.1108/SCM-04-2012-0152

Bansal, P. (2005). Evolving Sustainably: A Longitudinal Study of Corporate Sustainable Development. Strategic Management Journal, 26, 197-218. https://doi.org/10.1002/smj.441

Bansal, P., \& Roth, K. (2000). Why Companies Go Green: A Model of Ecological Responsiveness. Academy of Management Journal, 43, 717-736.

https://doi.org/10.5465/1556363

Bar-Haim, A., \& Karassin, O. (2018). A Multilevel Model of Responsibility towards Employees as a Dimension of Corporate Social Responsibility. Journal of Management and Sustainability, 8, 1-15. https://doi.org/10.5539/jms.v8n3p1

Baumann-Pauly, D., Wickert, C., Spence, L. J., \& Scherer, A. G. (2013). Organizing Corporate Social Responsibility in Small and Large Firms: Size Matters. Journal of Business Ethics, 115, 693-705. https://doi.org/10.1007/s10551-013-1827-7

Bell, S. (2015). http://www.worldbank.org/en/topic/financialsector/brief/smes-finance

Ben Israel, R. (2002). Employment Law. Volume II. The Open University of Israel Publishing. (In Hebrew)

Bhatt, P., \& Reddy, S. C. (2011). HRM Practices and Its Impact on Performance-Exploratory Literature Review in the Context of Indian SMEs. National Journal of Research in Management, 1, 73-87.

https://search.proquest.com/docview/1478002292?accountid=12994

Bondy, K., Moon, J., \& Matten, D. (2012). An Institution of Corporate Social Responsibility (CSR) in Multi-National Corporations (MNCs): Form and Implications. Journal of Business Ethics, 111, 281-299. https://doi.org/10.1007/s10551-012-1208-7

Boselie, P., Brewster, C., \& Paauwe, J. (2009). In Search of Balance-Managing the Dualities of HRM: An Overview of the Issues. Personnel Review, 38, 461-471. https://doi.org/10.1108/00483480910977992

Bowen, H. R. (1953). Social Responsibility of the Businessman. Harper and Row.

Brand, M. J., \& Bax, E. H. (2002). Strategic HRM for SMEs: Implications for Firms and Policy. Education \& Training, 44, 451-463. https://search.proquest.com/docview/237087153?accountid=12994 https://doi.org/10.1108/0040091020449295

Buciuniene, I., \& Kazlauskaite, R. (2012). The Linkage between HRM, CSR and Performance Outcomes. Baltic Journal of Management, 7, 5-24. https://doi.org/10.1108/17465261211195856

Burke, R. J. (2011). Human Resource Management in Small- and Medium-Sized Enterprises: Benefits and Challenges (Ch. 2). In C. L. Cooper, \& R. J. Burke (Eds.), Human Resource Management in Small Business: Achieving Peak Performance (pp. 10-70). Edward Elgar.

Campbell, J. L. (2007). Why Would Corporations Behave in Socially Responsible Ways? An Institutional Theory of Corporate Social Responsibility. Academy of Management Review, 32, 946-967. https://doi.org/10.5465/amr.2007.25275684

Chanut-Guieu, C., \& Guieu, G. C. (2014). High Growth Trajectories in Small and Me- 
dium Sized Enterprises: A Comparative study. Journal of Small Business and Enterprise Development, 21, 623-637. https://doi.org/10.1108/JSBED-09-2014-0151

Chapple, W., \& Moon, J. (2005). Corporate Social Responsibility (CSR) in Asia: A Seven-Country Study of SCR Web Site Reporting. Business \& Society, 44, 415-441. https://doi.org/10.1177/0007650305281658

Chen, S.-Y., Chuang, C., \& Chen, S. (2018). A Conceptual Review of Human Resource Management Research and Practice in Taiwan with Comparison to Select Economies in East Asia. Asia Pacific Journal of Management, 35, 213-239. https://doi.org/10.1007/s10490-017-9516-1

Chitiba, C. A. (2014). European Policy for Small and Medium Enterprises. Knowledge Horizons-Economics, 6, 30-33. http://www.orizonturi.ucdc.ro/arhiva/2014 khe 62 pdf/khe vol 6 iss 2 30to33.pdf

Clarkson, M. E. (1995). A Stakeholder Framework for Analyzing and Evaluating Corporate Social Performance. Academy of Management Review, 20, 92-117. https://doi.org/10.2307/258888

Compa, L. (2008). Corporate Social Responsibility and Workers' Rights. Comparative Labour Law \& Policy Journal, 30, 1-10. https://heinonline.org/HOL/LandingPage?handle=hein.journals/cllpj30\&div=4\&id=\&p age $=$

Cooper, C. L., \& Burke, R. J. (Eds.) (2011). Human Resource Management in Small Business: Achieving Peak Performance. Edward Elgar. https://doi.org/10.4337/9780857933195

Corcoran, D. J., \& Shackman, J. D. (2007). A Theoretical and Empirical Analysis of the Strategic Value of Beyond Compliance Occupational, Health and Safety Programs. Journal of Business Strategies, 24, 49-68. https://doi.org/10.54155/jbs.24.1.49-68

Crowther, D., \& Guler, A. G. (2010). Corporate Social Responsibility: Part I Principles, Stakeholders \& Sustainability. Ventus Publishing.

Dabić, M., Maley, J., Dana, L.-P., Novak, I., Pellegrini, M. M., \& Caputo, A. (2020). Pathways of SME Internationalization: A Bibliometric and Systematic Review. Small Business Economics, 55, 705-725. https://doi.org/10.1007/s11187-019-00181-6

Dahlsrud, A. (2008). How Corporate Social Responsibility Is Defined: An Analysis of 37 Definitions. Corporate Social Responsibility and Environmental Management, 15, 1-13. https://doi.org/10.1002/csr.132

Ditlev-Simonsen, C., \& Wenstøp, F. (2013). How Stakeholders View Stakeholders as CSR Motivators. Social Responsibility Journal, 9, 137-147. https://doi.org/10.1108/17471111311307868

Donaldson, T., \& Preston, L. E. (1995). The Stakeholder Theory of the Corporation: Concepts, Evidence, and Implications. Academy of Management Review, 20, 65-91. https://doi.org/10.2307/258887

Edwards, T., Sánchez-Mangas, R., Jalette, P., Lavelle, J., \& Minbaeva, D. (2016). Global Standardization or National Differentiation of HRM Practices in Multinational Companies? A Comparison of Multinationals in Five Countries. Journal of International Business Studies, 47, 997-1021. https://doi.org/10.1057/s41267-016-0003-6

Fabi, B., Raymond, L., \& Lacoursière, R. (2009). Strategic Alignment of HRM Practices in Manufacturing SMEs: A Gestalts Perspective. Journal of Small Business and Enterprise Development, 16, 7-25. https://doi.org/10.1108/14626000910932854

Freeman, R. E. (1984). Strategic Management: A Stakeholder Approach (Pitman Series in Business and Public Policy). Harpercollins College Div. 
Graafland, J., \& Smid, H. (2019). Decoupling among CSR Policies, Programs, and Impacts: An Empirical Study. Business \& Society, 58, 231-267. https://doi.org/10.1177/0007650316647951

Graafland, J., Kaptein, M., \& van der Duijn Schouten, C. M. (2007). Conceptions of God, Normative Convictions, and Socially Responsible Business Conduct: An Explorative Study among Executives. Business and Society, 46, 331-368.

https://doi.org/10.1177/0007650306296085

Harney, B., \& Dundon, T. (2006). Capturing Complexity: Developing an Integrated Approach to Analysing HRM in SMEs. Human Resource Management Journal, 16, 48-73. https://doi.org/10.1111/j.1748-8583.2006.00004.x

Harney, B., \& Nolan, C. (2014). HRM in Small and Medium-Sized Firms (SMEs). In B. Harney, \& K. Monks (Eds.), Strategic HRM: Research and Practice in Ireland (pp. 153-169). Blackhall/Orpen.

Harrison, J. S., \& Freeman, R. E. (1999). Stakeholders, Social Responsibility, and Performance: Empirical Evidence and Theoretical Perspectives. Academy of Management Journal, 42, 479-485. https://doi.org/10.5465/256971

Hemingway, C. A. (2005). The Role of Personal Values in Corporate Social Entrepreneurship. ICCSR Research Paper Series, 31, Nottingham University Business School, University of Nottingham.

Hsu, J., \& Cheng, M. (2012). What Prompts Small and Medium Enterprises to Engage in Corporate Social Responsibility? A Study from Taiwan. Corporate Social Responsibility and Environmental Management, 19, 288-305. https://doi.org/10.1002/csr.276

Jackson, G., \& Rathert, N. (2016). Private Governance as Regulatory Substitute or Complement? A Comparative Institutional Approach to CSR Adoption by Multinational Corporations. In C. DöRrenbächer, \& M. Geppert (Eds.), Multinational Corporations and Organization Theory: Post Millennium Perspectives (Research in the Sociology of Organizations, Volume 49) (pp. 445-478). Emerald Publishing Limited. https://doi.org/10.1108/S0733-558X20160000049015

Jackson, G., \& Apostolakou, A. (2010). Corporate Social Responsibility in Western Europe: An Institutional Mirror or Substitute? Journal of Business Ethics, 94, 371-394. https://doi.org/10.1007/s10551-009-0269-8

Jamali, D. (2010). MNCs and International Accountability Standards through an Institutional Lens: Evidence of Symbolic Conformity or Decoupling. Journal of Business Ethics, 95, 617-640. https://doi.org/10.1007/s10551-010-0443-Z

Jamali, D., Zanhour, M., \& Keshishian, T. (2009). Peculiar Strengths and Relational Attributes of SMEs in CSR Context. Journal of Business Ethics, 87, 355-377. https://doi.org/10.1007/s10551-008-9925-7

Jenkins, H. (2004). A Critique of Conventional CSR Theory: An SME Perspective. Journal of General Management, 29, 37-57.

https://search.proquest.com/docview/196399195?accountid=12994 https://doi.org/10.1177/030630700402900403

Jenkins, H. (2006). Small Business Champions for Corporate Social Responsibility. Journal of Business Ethics, 67, 241-256. https://doi.org/10.1007/s10551-006-9182-6

Kaplan, R., \& Kinderman, D. (2017). The Business-Led Globalization of CSR: Channels of Diffusion from the United States into Venezuela and Britain, 1962-1981. Business \& Society, 59, 439-488. https://doi.org/10.1177/0007650317717958

Karadag, H. (2017). The Impact of Industry, Firm Age and Education Level on Financial Management Performance in Small and Medium-Sized Enterprises (SMEs). Journal of Entrepreneurship in Emerging Economies, 9, 300-314. 
https://doi.org/10.1108/JEEE-09-2016-0037

Karassin, O., \& Bar-Haim, A. (2016). Multilevel Corporate Environmental Responsibility. Journal of Environmental Management, 183, 110-120.

https://doi.org/10.1016/j.jenvman.2016.08.051

Karassin, O., \& Bar-Haim, A. (2019). How Regulation Effects Corporate Social Responsibility: Corporate Environmental Performance under Different Regulatory Scenarios. World Political Science Review, 15, 25-53. https://doi.org/10.1515/wps-2019-0005

Kercher, K. (2007). Corporate Social Responsibility: Impact of Globalisation and International Business. http://epublications.bond.edu.au/cgej/4

Kinderman, D. (2009). Why Do Some Countries Get CSR Sooner, and in Greater Quantity, than Others? The Political Economy of Corporate Responsibility and the Rise of Market Liberalism across the OECD: 1977-2007. Discussion Paper SP III 2009-301, Wissenschaftszentrum Berlin für Sozialforschung gGmbH (WZB).

Kinnie, N., Purcell, J., Hutchinson, S., Terry, M. C., \& Scarbrough, H. (1999). Employment Relations in SMEs Market-Driven or Customer-Shaped? Employee Relations, 21, 218-235. https://doi.org/10.1108/01425459910273071

Kundu, S. C., \& Gahlawat, N. (2015). Effects of CSR Focused HRM on Employees Satisfaction: A Study of Indian Organisations. Journal of Strategic Human Resource Management, 4, 42-48. https://doi.org/10.21863/jshrm/2015.4.2.007

Kusyk, S. M., \& Lozano, J. M. (2007). SME Social Performance: A Four-Cell Typology of Key Drivers and Barriers on Social Issues and Their Implications for Stakeholder Theory. Corporate Governance: The International Journal of Business in Society, 7, 502-515. https://doi.org/10.1108/14720700710820588

Kwiatkowska, W. (2010). The Growth of the Small and Medium-Sized Enterprises in the Polish Economy and Their Influence on the Labour Market. Comparative Economic Research, 13, 5-21. https://doi.org/10.2478/v10103-009-0027-2

Lee, K., Herold, D. M., \& Yu, A. (2016). Small and Medium Enterprises and Corporate Social Responsibility Practice: A Swedish Perspective. Corporate Social Responsibility and Environmental Management, 23, 88-99. https://doi.org/10.1002/csr.1366

Lenox, M. J., \& Nash, J. (2003). Industry Self-Regulation and Adverse Selection: A Comparison across Four Trade Association Programs. Business Strategy and the Environment, 12, 343-356. https://doi.org/10.1002/bse.380

Lepoutre, J., \& Heene, A. (2006). Investigating the Impact of Firm Size on Small Business Social Responsibility: A Critical Review. Journal of Business Ethics, 67, 257-273. https://doi.org/10.1007/s10551-006-9183-5

Levy, D. L., \& Brown, H. S. (2012). The Global Reporting Initiative, Promise and Limitations. In D. Reed, P. Utting, \& A. Mukherjee-Reed (Eds.), Business Regulation and Non-State Actors: Whose Standards? Whose Development? (pp. 109-121). Routledge.

Longo, M., Mura, M., \& Bonoli, A. (2005). Corporate Social Responsibility and Corporate Performance: The Case of Italian SMEs. Corporate Governance, 5, 28-42. https://search.proquest.com/docview/205207184?accountid=12994 https://doi.org/10.1108/14720700510616578

Lurie, L. (2013). Employment and Social Security Laws in the Twenty First Century. Nevo Publishing. (In Hebrew)

Maharjan, M. P., \& Sekiguchi, T. (2016). Human Resource Management Practices at Foreign-Affiliated Companies in Least-Developed Regions: US and Japanese Companies in Nepal. Asian Business \& Management, 15, 137-164. https://doi.org/10.1057/abm.2016.6

Mallett, O., \& Wapshott, R. (2017). Small Business Revivalism: Employment Relations in 
Small and Medium-Sized Enterprises. Work, Employment \& Society, 31, 719-726. https://doi.org/10.1177/0950017017690503

Meulman, J. J., Van der Kooij, A. J., \& Heiser, W. J. (2004). Principal Components Analysis with Nonlinear Optimal Scaling Transformations for Ordinal and Nominal Data. In D. Kaplan (Ed.), Handbook of Quantitative Methods in the Social Sciences (pp. 49-70). Sage Publications. https://doi.org/10.4135/9781412986311.n3

Mijatovic, I. S., \& Stokic, D. (2010). The Influence of Internal and External Codes on CSR Practice: The Case of Companies Operating in Serbia. Journal of Business Ethics, 94, 533-552. https://doi.org/10.1007/s10551-009-0280-0

Mohr, L. A., \& Webb, D. J. (2005). The Effects of Corporate Social Responsibility and Price on Consumer Responses. The Journal of Consumer Affairs, 39, 121-147. https://doi.org/10.1111/j.1745-6606.2005.00006.x

Montero, M. J., Araque, R. A., \& Rey, J. M. (2009). Occupational Health and Safety in the Framework of Corporate Social Responsibility. Safety Science, 47, 1440-1445. https://doi.org/10.1016/j.ssci.2009.03.002

Morsing, M., \& Perrini, F. (2009). CSR in SMEs: Do SMEs Matter for the CSR Agenda? Business Ethics, 18, 1-6. https://doi.org/10.1111/j.1467-8608.2009.01544.x

Mousiolis, D. T., Zaridis, A. D., Karamanis, K., \& Rontogianni, A. (2015). Corporate Social Responsibility in SMEs and MNEs. The Different Strategic Decision Making. Procedia-Social and Behavioral Sciences, 175, 579-583.

Mudrack, P. (2007). Individual Personality Factors That Affect Normative Beliefs about the Rightness of Corporate Social Responsibility. Business \& Society, 46, 33-62. https://doi.org/10.1177/0007650306290312

Nielsen, A. E., \& Thomsen, C. (2009). Investigating CSR Communication in SMEs: A Case Study among Danish Middle Managers. Business Ethics, 18, 83-93. https://doi.org/10.1111/j.1467-8608.2009.01550.x

Novicevic, M. M., Hayek, M., \& Fang, T. (2011). Integrating Barnard's and Contemporary Views of Industrial Relations and HRM. Journal of Management History, 17, 126-138. https://doi.org/10.1108/17511341111099547

O’Connor, A., Parcha, J. M., \& Tulibaski, K. L. G. (2017). The Institutionalization of Corporate Social Responsibility Communication: An Intra-Industry Comparison of MNCs' and SMEs' CSR Reports. Management Communication Quarterly, 31, 503-532. https://doi.org/10.1177/0893318917704512

O’Riordan, L., \& Fairbanks, J. (2014). Managing CSR Stakeholder Engagement: A New Conceptual Framework. Journal of Business Ethics, 125, 121-145. https://doi.org/10.1007/s10551-013-1913-x

OECD (2011). Guidelines for Multinational Enterprises (2011 ed.). https://www.oecd.org/corporate/mne/48004323.pdf

Okhmatovskiy, I., \& David, R. J. (2012). Setting Your Own Standards: Internal Corporate Governance Codes as a Response to Institutional Pressure. Organization Science, 23, 155-176. https://doi.org/10.1287/orsc.1100.0642

Orlitzky, M., Louche, C., Gond, J. P., \& Chapple, W. (2017). Unpacking the Drivers of Corporate Social Performance: A Multilevel, Multistakeholder, and Multimethod Analysis. Journal of Business Ethics, 144, 21-40. https://doi.org/10.1007/s10551-015-2822-y

Parker, R. (2000). Small Is Not Necessarily Beautiful: An Evaluation of Policy Support for Small and Medium-Sized Enterprises in Australia. Australian Journal of Political Science, 35, 239-253. https://search.proquest.com/docview/204374532? accountid=12994 
https://doi.org/10.1080/713649330

Preuss, L. (2019). Tracing the Global Diffusion of Corporate Social Responsibility. In Academy of Management Proceedings (Vol. 2019, No. 1, p. 13832). Briarcliff Manor, NY 10510: Academy of Management. https://journals.aom.org/doi/abs/10.5465/AMBPP.2019.13832abstract

Preuss, L., Haunschild, A., \& Matten, D. (2009). The Rise of CSR: Implications for HRM and Employee Representation. The International Journal of Human Resource Management, 20, 953-973. https://doi.org/10.1080/09585190902770893

Remišová, A., \& Búciová, Z. (2012). Measuring Corporate Social Responsibility towards Employees. Journal for East European Management Studies, 17, 273-291. https://doi.org/10.5771/0949-6181-2012-3-273

Rodriguez, J. K., \& Gomez, C. F. (2009). HRM in Chile: The Impact of Organisational Culture. Employee Relations, 31, 276-294. https://doi.org/10.1108/01425450910946479

Sánchez, P. E., \& Benito-Hernández, S. (2015). CSR Policies: Effects on Labour Productivity in Spanish Micro and Small Manufacturing Companies. Journal of Business Ethics, 128, 705-724. https://doi.org/10.1007/s10551-013-1982-x

Scherer, A. G., \& Palazzo, G. (2011). The New Political Role of Business in a Globalized World: A Review of a New Perspective on CSR and Its Implications for the Firm, Governance, and Democracy. Journal of Management Studies, 48, 899-931. https://doi.org/10.1111/j.1467-6486.2010.00950.x

Sethi, S. P. (1975). Dimensions of Corporate Social Performance: An Analytical Framework. California Management Review, 17, 58-64. https://doi.org/10.2307/41162149

Sheehan, M. (2013). Human Resource Management and Performance: Evidence from Small and Medium-Sized Firms. International Small Business Journal, 32, 545-570. https://doi.org/10.1177/0266242612465454

Spence, L. J. (2007). CSR and Small Business in a European Policy Context: The Five "C"s of CSR and Small Business Research Agenda 2007. Business and Society Review, 112, 533-552. https://doi.org/10.1111/j.1467-8594.2007.00308.x

Srinivasan, V., \& Arora, B. (2015). 19. Examining HRM-LA and CSR Linkages in the Context of Emerging Economies: The Indian Experience. In F. Horwitz, \& P. Budhwar (Eds.), Handbook of Human Resource Management in Emerging Markets (pp. 429-450). Edward Elgar Publishing https://doi.org/10.4337/9781781955017.00030

Staehle, W., \& Schirmer, F. (1992). Lower-Level and Middle-Level Managers as the Recipients and Actors of Human-Resource Management. International Studies of Management \& Organization, 22, 67-89. https://doi.org/10.1080/00208825.1992.11656576

Strike, V. M., Gao, J., \& Bansal, P. (2006). Being Good While Being Bad: Social Responsibility and the International Diversification of US Firms. Journal of International Business Studies, 37, 850-862. https://doi.org/10.1057/palgrave.jibs.8400226

Sumetzberger, W. (2005). Managing Human Resources in a Multinational Context. Journal of European Industrial Training, 29, 663-674. https://doi.org/10.1108/03090590510627120

Surroca, J., Tribỏ, J. A., \& Zahra, S. A. (2013). Stakeholder Pressure on MNEs and the Transfer of Socially Irresponsible Practices to Subsidiaries. Academy of Management Journal, 56, 549-572. https://doi.org/10.5465/amj.2010.0962

Sweeney, L. (2007). Corporate Social Responsibility in Ireland: Barriers and Opportunities Experienced by SMEs When Undertaking CSR. Corporate Governance, 7, 516-523. https://doi.org/10.1108/14720700710820597

Tengblad, S., \& Ohlsson, C. (2010). The Framing of Corporate Social Responsibility and 
the Globalization of National Business Systems: A Longitudinal Case Study. Journal of Business Ethics, 93, 653-669. https://doi.org/10.1007/s10551-009-0246-2

Teramae, F., Makino, T., Lim, Y., Sengoku, S., \& Kodama, K. (2020). Impact of Research and Development Strategy on Sustainable Growth in Multinational Pharmaceutical Companies. Sustainability, 12, Article 5358. https://doi.org/10.3390/su12135358

Thornton, D., Kagan, R. A., \& Gunningham N. (2009). When Social Norms and Pressures Are Not Enough: Environmental Performance in the Trucking Industry. Law \& Society Review, 43, 405-436. https://doi.org/10.1111/j.1540-5893.2009.00377.x

Tsai, C. (2010). HRM in SMEs: Homogeneity or Heterogeneity? A Study of Taiwanese High-Tech Firms. The International Journal of Human Resource Management, 21, 1689-1711. https://doi.org/10.1080/09585192.2010.500490

van Erp, J. (2011). Naming and Shaming in Regulatory Enforcement. In C. Parker, \& V. Lehmann-Nielsen (Eds.), Explaining Compliance, Business Responses to Regulation (pp. 322-343). Edward Elgar. https://doi.org/10.4337/9780857938732.00023

Vo, L. C. (2011). Corporate Social Responsibility and SMEs: A Literature Review and Agenda for Future Research. Problems and Perspectives in Management, 9, 89-97.

Waddock, S. A., \& Graves, S. B. (1997). The Corporate Social Performance-Financial Performance Link. Strategic Management Journal, 18, 303-319. https://doi.org/10.1002/(SICI)1097-0266(199704)18:4<303::AID-SMJ869>3.0.CO;2-G

Weaver, G. R., Treviño, L. K., \& Cochran, P. L. (1999a). Corporate Ethics Programs as Control Systems: Influences of Executive Commitment and Environmental Factors. Academy of Management Journal, 42, 41-57. https://doi.org/10.2307/256873

Weaver, G. R., Treviño, L. K., \& Cochran, P. L. (1999b). Integrated and Decoupled Corporate Social Performance: Management Commitments, External Pressures, and Corporate Ethics Practices. Academy of Management Journal, 42, 539-552. https://doi.org/10.2307/256975

Wilburn, K., \& Wilburn, R. (2013). Using Global Reporting Initiative Indicators CSR Programs. Journal of Global Responsibility, 4, 62-75. https://doi.org/10.1108/20412561311324078

Wilkinson, A. (1999). Employment Relations in SMEs. Employee Relations, 21, 206-217. https://doi.org/10.1108/01425459910273062

Williamson, D., Lynch-Wood, G., \& Ramsay, J. (2006). Drivers of Environmental Behaviour in Manufacturing SMEs and the Implications for CSR. Journal of Business Ethics, $67,317-330$.

Xiang, D., \& Worthington, A. (2015). Finance-Seeking Behaviour and Outcomes for Small- and Medium-Sized Enterprises. International Journal of Managerial Finance, 11, 513-530. https://doi.org/10.1108/IJMF-01-2013-0005

Yu, G., Park, W., \& Cho, Y. (2007). MNCs' HRM Strategy and Country of Origin Effect: Do North American, European and Japanese Firms Really Differ? Management Revue, 18, 392-409. https://search.proquest.com/docview/201521959? accountid=12994 https://doi.org/10.5771/0935-9915-2007-4-392 